\title{
In Vitro Testing to Aflatoxin Binding by Glucomannan Yeast Product and Glucomannan Extract from Amorphophallus oncophyllus
}

\author{
A. Susanto ${ }^{\mathrm{a}, \mathrm{b}, *}$, E. B. Laconi ${ }^{\mathrm{c}, *}$, D. A. Astuti ${ }^{\mathrm{c}}$, \& S.Bahri ${ }^{\mathrm{d}}$ \\ a Study Program of Animal Nutrition and Feed Science, Graduate School, Bogor Agricultural University \\ ${ }^{b}$ Feed Assay Laboratory \\ Jln. MT. Haryono 98, Setu, Bekasi, West Java, Indonesia \\ cDepartment of Animal Nutrition and Feed Technology, Faculty of Animal Science, Bogor Agricultural University \\ Jln. Agatis, Kampus IPB Darmaga, Bogor 16680, Indonesia \\ dIndonesian Center for Animal Research and Development \\ Jln. Raya Pajajaran Kav E-59 Bogor 16151, Indonesia \\ (Received 24-04-2014; Reviewed 26-05-2014; Accepted 03-07-2014)
}

\begin{abstract}
The aim of research was to test the capability of glucomannan yeast product (GYP) and glucomannan resulted from Amorphophallus oncophyllus extraction (GRE) to bind aflatoxin in in vitro testing. Before in vitro testing, both GYP and GRE were analyzed to determine proximate analysis, glucose, and mannose concentrations. In vitro testing used aflatoxin, binder and gastro intestinal fluid in $3 \%$ ringer solution. The weights of binders were $41.05 ; 82.1 ; 123.15$; and $164.2 \mathrm{mg}$ and weight of aflatoxin was $0.1642 \mu \mathrm{g}$ of each tube. The results showed that the percentage of aflatoxin bound increased by the increasing weight either glucomannan from yeast product or glucomannan resulted from $A$. oncophylus extraction. The percentages of aflatoxin binding with binder of both glucomannan yeast product were $19.72 \% ; 21.51 \% ; 42.25 \% ; 46.35 \%$ and glucomannan from $A$. oncophyllus extraction were 4.08\%; $28.72 \%$; 36.73\%; and $89.07 \%$, consecutively. There were positive correlations $(P<0.05)$ between the weight of binder and the percentage of aflatoxin bound, with coefficient correlations of GYP was 0.9602 and of GRE was 0.9338. In regression modeling, linear equation of GYP was $Y p=-6.92+12.03 x$ and of GRE was $\mathrm{Ye}=-31.53+21.07 \mathrm{x}$. It is concluded that in vitro testing of glucomannan product of extraction from A. oncophyllus can bind aflatoxin.
\end{abstract}

Key words: aflatoxin, binding, glucomannan, in vitro

\section{ABSTRAK}

Penelitian ini bertujuan untuk menguji kemampuan glucomannan yeast product (GYP) dan glucomannan hasil ekstraksi dari Amorphophallus oncophylus (GRE) dalam mengikat aflatoksin dengan uji in vitro. Sebelum diuji in vitro, GYP dan GRE diuji proksimat, glukosa dan mannosa. Uji in vitro menggunakan aflatoksin, bahan pengikat (GYP dan GRE), cairan gastro intestinum ayam broiler $3 \%$ dalam larutan ringer. Bobot bahan pengikat adalah 41,05; 82,1; 123,15; dan 164,2 mg dan bobot aflatoksin $0,1642 \mu \mathrm{g}$ di setiap tabung. Hasil penelitian menunjukkan persentase pengikatan aflatoksin meningkat sesuai dengan bertambahnya bobot bahan pengikat baik GYP maupun GEA. Persentase daya ikat aflatoksin GYP adalah $19,72 \% ; 21,51 \% ; 42,25 \% ; 46,35 \%$ dan GEA adalah $4,08 \%$; $28,72 \%$; 36,73\%; dan $89.07 \%$. Hubungan antara bobot GYP dan GEA memiliki korelasi positif yang signifikan $(\mathrm{P}<0,05)$ dengan nilai koefisien korelasi untuk GYP adalah 0,9602 dan GEA adalah 0,9338 . Persamaan regresi dari GYP adalah $Y p=-6,92+12,03 X$, sedangkan untuk GEA adalah $Y e=-$ $31,53+21,07 \mathrm{X}$. Kesimpulan dari penelitian ini bahwa secara in vitro glukomannan hasil ekstraksi $A$. oncophyllus mampu mengikat aflatoksin.

Kata kunci: aflatoksin, pengikatan, glucomannan, in vitro

*Corresponding author:

E-mail: agus_equilibrium@yahoo.com; elaconi@yahoo.com 


\section{INTRODUCTION}

Feed determines productivity of livestock and affects the safety of animal products for human consumption. Good quality of feed will give good quality of livestock products such as egg, milk, meat and wool. Recently, feed industry formulated animal feed based on corn and soybean components. Corn, which it's usage in feed formulation is high, is easily attacked by Aspergillus flavus, so that feed containing corn is easily contaminated by aflatoxin. A. flavus and A. parasiticus are the main producer of afatoxin (Richard et al., 2009). There are approximately 20 related metabolites of aflatoxin, among which are aflatoxin B1, B2, G1, and G2 (Siddappa et al., 2012).

Aflatoxin causes health disorders in animal and human, because aflatoxin is carcinogenic level 1 (International Agency for Research on Cancer, 2012). Animals which are susceptible to contamination of aflatoxin are fish, poultry (duck, turkey, chicken and quail), and mammal. The adverse effects of consuming feeds containing aflatoxin are depressed appetite, reduced growth rate, reduced reproductive function and milk output in breeding livestock, suppressed immune function and general sub-standard performance. Aflatoxin causes petechial hemorrhages in the liver and kidneys of broiler chicken and increased the weight of liver (Denli et al., 2009).

Extensive research has been conducted to prevent mycotoxicosis but the aspects studies are mainly physical, chemical, nutritional and biological approaches. At present, most commercial aflatoxin binders are glucomannan containing yeast product (Girish \& Devewgoda 2006), hydrated sodium calcium aluminosilicate (Akkaya \& Bal, 2012), zeolite (Kaki et al., 2012), bentonite (Nuryono et al., 2012), kaolin (Hesham, 2004), and activated carbon (Gallo \& Masoer, 2010). Glucomannan are shown to have binding potential for aflatoxin. Devegowda \& Murthy (2005) reported that GYP, obtained from cell wall of Saccharomyces cerevisiae had the capacity to bind with mycotoxin. However, the source of glucomannans is not only the cell wall of S. cerevisae. Glucomannan has also been extracted from the tuber of A. oncophylus plant.

It is accepted that before we conducted in vivo testing of glucomannan from yeast and glucomannan extracted from $A$. oncophyllus as a potential aflatoxin binder, we had to conduct an in vitro test to determine their activities. Although result of in vitro testing is not always similar to in vivo testing, in vitro testing can screen material which can bind mycotoxin. In vitro experiment is simpler than in vivo experiment because in vitro testing only uses parts of biological components such as fluid of intestine, saliva, etc. whereas in in vivo experiment, the testing is conducted in live animal. Therefore, this experiment aimed to test the capability of glucomannan product extracted from A. oncophylus to bind aflatoxin with in vitro testing.

\section{MATERIALS AND METHODS}

\section{Materials}

Glucomannan used in this experiment were mycosorb $^{\circledR}$ as glucomannan yeast product (GYP) and glucomannan extracted from $A$. oncophylus (GRE) by ethanol extraction. Ringer lactate solution and gastro intestinal solution of broiler chicken were used to dissolve binder and aflatoxin (Biopure ${ }^{\circledR}$ ) in test tube.

Glucomannan extracted from A. oncophylus. Tubers $A$. oncophyllus were collected from Sambit, Ponorogo, East Java, Indonesia. The skins of tuber $A$. oncophylus were peeled and pulp, for further slicing with $0.5 \mathrm{~cm}$ thickness. Slices of $A$. oncophylus were oven-dried at $80^{\circ} \mathrm{C}$ for $8 \mathrm{~h}$. Dried slices were grinded and sifted with 100 mesh sieve. The powder obtained from A. oncophylus was boiled in a glass (water: $30 \mathrm{~mL} / \mathrm{g}$ flour), at a temperature of $45^{\circ} \mathrm{C}$ with stirring for $1 \mathrm{~h}$. When the powder from the tuber of $A$. oncophylus formed a jelly-like texture, it was put in room temperature and filled with ethanol 96\% (1:2) and then stirred and sieved. The resulted extract was poured on aluminum foil, and dried in oven at $60{ }^{\circ} \mathrm{C}$ for $48 \mathrm{~h}$. Dried powder was ground to obtain flour of glucomannan extract of $A$. oncophylus (GRE).

\section{Methods}

Chemical analysis. The GYP and GRE were analyzed by proximate method including moisture, ash, crude protein, crude fiber and fat. Method of testing used National Standard Indonesia 01- 2891-1992 about Food and Beverages test methods. Moisture content was analyzed by drying with oven at $105^{\circ} \mathrm{C}$ for $3 \mathrm{~h}$ and ash was analyzed by using muffle furnace at $550{ }^{\circ} \mathrm{C}$ for $3 \mathrm{~h}$. Crude protein was analyzed by using kjeldahl method with 3 stages including destruction with $\mathrm{H}_{2} \mathrm{SO}_{4}$, distillation and nitrogen titration with $\mathrm{NaOH}$. Crude protein was calculated from concentration of nitrogen obtained that was multiplied by 6.25 . Crude fiber was obtained by extraction of sample with $\mathrm{H}_{2} \mathrm{SO}_{4} 1.25 \%$ and $\mathrm{NaOH} 3.25 \%$. Concentration of crude fat was obtained by extraction of sample with hexane.

Glucose content was tested by method of SNI 01-2891-1992 clausul 9, which was based on titrimetry. Sample with $5 \mathrm{~g}$ weight was filled in Erlenmeyer tube and added $\mathrm{HCl} \mathrm{3 \%}$, then boiled for $3 \mathrm{~h}$. After cooling, $\mathrm{NaOH} 30 \%$ and several drops of $\mathrm{CH}_{3} \mathrm{COOH} 3 \%$ were added. Ten milliliters of liquid samples were filled in Erlemeyer tube and added $25 \mathrm{~mL}$ Luff Schoorl and 15 $\mathrm{mL}$ aquadest and then was boiled for $10 \mathrm{~min}$. After cooling, $15 \mathrm{~mL}$ of $\mathrm{KI} 20 \%$ and $25 \mathrm{~mL} \mathrm{H}_{2} \mathrm{SO}_{4}$ were added and titrated with Tio $0.1 \mathrm{~N}$.

Analysis of mannan was conducted by using Ohtsuki method (Ohtsuki, 1968) and the other name of the method was Mannosa Phenylhydrazone. Sample with the weight of $1 \mathrm{~g}$ was filled in Erlenmeyer tube and added $50 \mathrm{~mL} \mathrm{HCl} 2 \%$ and boiled for $3 \mathrm{~h}$. The solution was neutralized by $\mathrm{NaOH}$ and added activated charcoal then filtered with whattman 41 filter. The filtrates were distillated to $10 \mathrm{~mL}$ and added $0.4 \mathrm{~g}$ phenylhydrazine 
hydrochloride, $0.65 \mathrm{~g}$ sodium acetate and $5 \mathrm{~mL}$ aquadest, and then placed in refrigerator for $24 \mathrm{~h}$. Sediment formed at the bottom of the solution was mannosaphenylhydrazine. Concentration of mannose was calculated by multiplying the weight of mannosaphenylhydrazine sediment with 0.67 .

In vitro procedure. In vitro testing was begun by preparation of solution $\mathrm{A}$ and solution $\mathrm{B}$. Stock of solution $\mathrm{A}$ was Aflatoxin B1 with concentration of $0.821 \mu \mathrm{g} / \mathrm{mL}$ and stock of solution B was gastro-intestinal fluid of chicken in 3\% ringer lactate. The binders to be tested (GYP and GRE) were weighted 41,05; 82,1; 123,15; and $164.2 \mathrm{mg}$ and put into test tubes, then $0,2 \mathrm{~mL}$ of solution A (aflatoxin $0.1642 \mu \mathrm{g}$ ) and $40 \mathrm{~mL}$ solution B were added to each test tube and gently shacked for $5 \mathrm{~min}$. Control samples $(\mathrm{n}=2)$ were prepared by adding $0.2 \mathrm{~mL}$ solution $\mathrm{A}$ and $40 \mathrm{~mL}$ solution $\mathrm{B}$ without binder. The ratios of aflatoxin: binder weights $(0.1642: 82,100 \mu \mathrm{g})$ used in the current study were designed to be about 1:500,000 (w/w), according to Aflatoxin: binder ratio used in our previous experiment (Moschini et al., 2008). This ratio was chosen to reflect possible field conditions.

All tubes were incubated in water bath at $39^{\circ} \mathrm{C}$ for $2 \mathrm{~h}$, and at the end of incubation period, all tubes were centrifuged (3500xg for15 $\mathrm{min}$ ) to separate supernatant from sediment. Supernatant was collected to analyze aflatoxin by ELISA (Enzyme Linked Immunosorbent Assay) with $450 \mathrm{~nm}$ wavelength. The Ridascreen test kit is a competitive enzyme immunoassay for the quantitative analysis of aflatoxin with limit detection of $<1.7 \mu \mathrm{g} / \mathrm{kg}$. If concentration of aflatoxin in supernatant was high, these indicated that the percentage of aflatoxin binding was low because aflatoxin was not bound by binder (precipitation). The ability to bind aflatoxin was expressed in the percentage of aflatoxin binding by using the following formula:

$$
\% \text { of aflatoxin binding }=\underline{(\mathrm{A}-\mathrm{B})} \times 100
$$

$$
\text { A }
$$

where:

$\mathrm{A}=$ Concentration of aflatoxin in supernatant from control (no binder)

$\mathrm{B}=$ Concentration of aflatoxin in supernatant from treatment

\section{Statistical Analysis}

Number of replication for every treatment and control were duplo $(n=2)$. Statistical analysis was performed by using descriptive statistics to show the percentage of aflatoxin binding. The differences between means of proximate analysis of GYP and GRE were compared by using $\mathrm{t}$ test. The correlation between weight of binder and the percentage of aflatoxin binding was calculated with the Pearson's correlation coefficient. When the weight of binder and percentage of aflatoxin had good correlation, the data were analyzed by regression analysis using IBM SPSS version 19. Significance was declared at $\mathrm{P}<0.05$.

\section{RESULTS AND DISCUSSION}

In vitro testing by ELISA showed that glucomannan from yeast product and glucomannan extracted from A. oncophylus could bind aflatoxin. Concentration of aflatoxin in supernatant and the percentage of aflatoxin binding (Table 1) supported the ELISA testing. Weight of binder would affect the ratio between the binder and aflatoxin, because the weights of aflatoxin were constant in each tube. Stock solution A $0.2 \mathrm{~mL}$ contained aflatoxin with concentration of $0.821 \mu \mathrm{g} / \mathrm{mL}$. Therefore, each tube of control or treatment had $0.1642 \mu \mathrm{g}$ aflatoxin. Weights of binder were $41.05 ; 82.1 ; 123.15$; and $164.2 \mathrm{mg}$ so the ratios with aflatoxin were $\mu \mathrm{g} 2.5 \times 10^{5} ; 5 \times 10^{5} ; 75 \times 10^{5}$ and $10^{6}$, respectively.

Increase in the weight of binder GYP and GRE caused the increase in the percentage of aflatoxin binding (Figure 1). If the weight of binder was high, the content of binder molecules would be high; thereby the probability of binder molecules to bind aflatoxin would increase. However, the ability to bind toxin or the percentage of toxin binding decreased as the number of toxins increased (Manafi et al., 2009).

Even though GRE was faster than GYP to achieve the optimal percentage of aflatoxin binding, such as weight of GRE $164.2 \mathrm{~g}$ can bind $89.07 \%$ but GYP was still $46.35 \%$ or in ratio of aflatoxin : binder were 1: $10^{6}$, GRE could bind aflatoxin by $89.07 \%$, on the other hand GYP only bound aflatoxin by $46.35 \%$. This condition was caused by the better ability of GRE to bind aflatoxin. Previous research (Gallo \& Masoero, 2010) showed the same result of ineffective or limited sequestering activity to aflatoxin were obtained with kaolinite and yeast cell wall-derived product (GYP) with in vitro method including a simply-water model $(\mathrm{W})$, gastro-intestinal stimulating monogastric model (MM) and ruminant model (RM).

Aflatoxin has relatively low molecular weight (312-330) with lipophilic molecule that appears to be absorbed rapidly and completely from gastro intestinal

\begin{tabular}{|c|c|c|c|c|}
\hline \multirow[b]{2}{*}{$\begin{array}{l}\text { Weight of binder } \\
\qquad(\mathrm{mg})\end{array}$} & \multicolumn{2}{|c|}{ Glucomannan Yeast Produt } & \multicolumn{2}{|c|}{ Extract Amorphophallus oncophyllus } \\
\hline & $\begin{array}{l}\text { Aflatoxin concentration } \\
\text { in supernatant }(\mu \mathrm{g} / \mathrm{L})\end{array}$ & $\begin{array}{c}\text { Percentage of aflatoxin } \\
\text { binding }(\%)\end{array}$ & $\begin{array}{l}\text { Aflatoxin concentration } \\
\text { in supernatant }(\mu \mathrm{g} / \mathrm{L})\end{array}$ & $\begin{array}{c}\text { Percentage of aflatoxin } \\
\text { binding }(\%)\end{array}$ \\
\hline 0 & $7.81 \pm 1.14$ & - & $6.86 \pm 0.04$ & - \\
\hline 41.05 & $6.27 \pm 0.07$ & 19.72 & $6.58 \pm 0.28$ & 4.08 \\
\hline 82.10 & $6.13 \pm 0.10$ & 21.51 & $4.89 \pm 1.13$ & 28.72 \\
\hline 123.15 & $4.51 \pm 0.19$ & 42.25 & $4.34 \pm 0.42$ & 36.73 \\
\hline 164.20 & $4.19 \pm 0.21$ & 46.35 & $0.75 \pm 0.16$ & 89.07 \\
\hline
\end{tabular}

Table 1. Aflatoxin concentration in supernatant and percentage of aflatoxin binding 


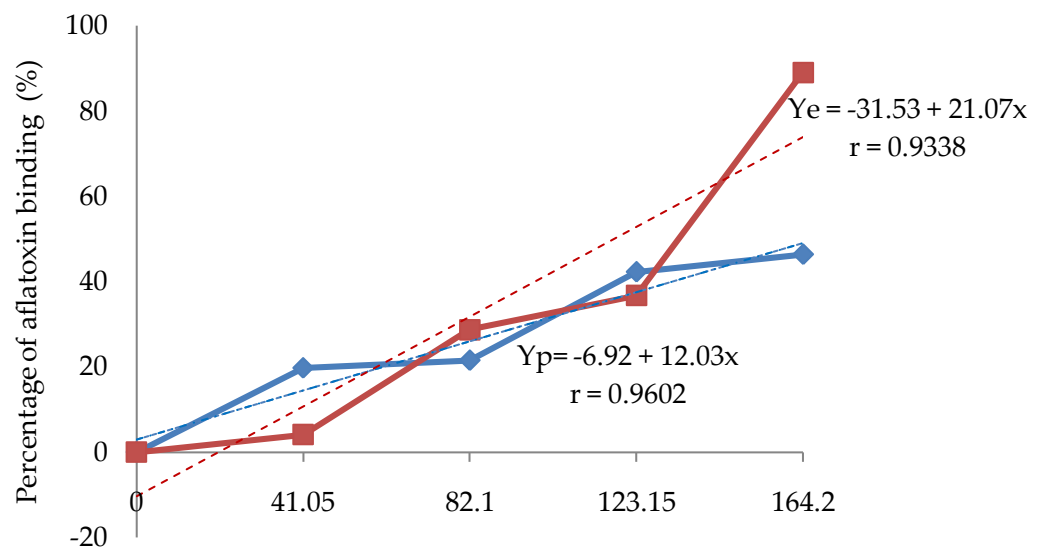

Weight of binder (mg)

Figure 1. Percentage of aflatoxin binding in glucomannan yeast product (- -) and glucomannan extracted from Amorphophallus oncophyllus (- - -).

tract (Rensburg et al., 2006). Molecular weight of GRE is $2.508 \times 10^{5} \mathrm{~g} / \mathrm{mol}$ by laser light scattering (LLS) single method (Xu et al., 2013). Based on the molecular weight, GRE is bigger than aflatoxin $(1: 781.3)$, so that GRE potentially bind aflatoxin, resulting in the formation a complex to minimize the risk of any rupture of the complex.

\section{Analysis of Regression}

Both data sets on the percentage of aflatoxin binding in GYP and GRE can be used to construct regression model and linear equation (Figure 1). Before attempting to fit a linear model, independent factor (weight of binder) should have a relationship with dependent factor (percentage aflatoxin binding) and this relationship was measured with correlation coefficient. GYP and GRE had correlation coefficients of 0.9602 and 0.9338 , respectively. It means that the weight of binder GYP and GRE have good relationship with percentage aflatoxin binding, although the value of correlation coefficient GYP was greater than GRE but both values were greater than 0.8 (strong correlation). Therefore, it can be continued to regression modeling.

The result of regression modeling was linear equation of GYP i.e., $Y p=-6.92+12.03 x$ and GRE is $\mathrm{Ye}=-31.53+21.07 \mathrm{x}$, the slope of the GYP line was 12.03, whereas that of GRE was 21.07. The slope of GYP (12.03) was lower than that of GRE (21.07), indicating that the weight of GRE was more sensitive than that of GYP. A slight increase in the weight of GRE would increase more percentage of aflatoxin binding. Thus the value percentage of aflatoxin binding in GRE was wider than in GYP. The percentage of aflatoxin binding in GRE was $0 \%-89.07 \%$ but in GYP was $0 \%-46.35 \%$.

\section{Ability to Bind Aflatoxin}

GYP and GRE were able to bind aflatoxin because GYP and GRE consisted almost entirely of proteins and carbohydrates (Table 2). The carbohydrate fraction is composed primarily of glucose, mannose, and $\mathrm{N}$ acetyglucosemine. Glucose and mannose, the two main sugars, were found in GYP and GRE. Concentrations of glucose and mannose obtained were $57.59 \%$ (glucose $31.89 \%$ and mannose $25.70 \%$ ) in GYP and $42.63 \%$ (glucose $27.43 \%$ and mannose $15.20 \%$ ) in GRE. Yeast mannan chains of various sizes are exposed on the external surface and are linked to cell wall proteins (Evans \& Dawson, 2007).

Compositions of protein and mannan in GYP with the ratio of almost $1: 1(28.63: 25.7)$ were consistent with those reported by Evan \& Dawson (2007). Further, Evan \& Dawson (2007) found that yeast cell wall consisted almost entirely of protein and carbohydrate. Glucose and mannose were present in about equal concentrations in GYP and GRE, although part of glucose of GRE was higher than GYP in the ratio of glucose : mannose. Ratio glucose and mannose was assumed to affect the percentage of aflatoxin binding. Ratio of glucose in GRE was higher than GYP, because the ratio glucose : mannose in GRE was 1.8:1 but in GYP was 1.2:1. Part of glucose in GRE was higher than in GYP in ratio of glucose-mannose due to GRE was originated from tuber of $A$. oncophylus plant that was stored as a product of photosynthesis. Meanwhile, ratio of glucose : mannose in GYP was 1.2:1, similar to result reported by Evan \& Dawson (2007) that glucose and mannose, the two main sugars, were present in about equal concentrations in $S$. cerevisae. The ratio of glucose and mannose in GYP

Table 2. The composition of glucomannan yeast product and glucomannan extracted from Amorphophallus oncophylus (\%)

\begin{tabular}{lccccc}
\hline Sample & Moisture & Crude protein & Crude fat & Crude fiber & Glucose \\
\hline GYP & $6.11 \pm 0.17^{\mathrm{a}}$ & $28.63 \pm 0.32^{\mathrm{b}}$ & $0.47 \pm 0.04^{\mathrm{a}}$ & $10.66 \pm 2.20^{\mathrm{a}}$ & $31.89 \pm 1.89^{\mathrm{b}}$ \\
GRE & $8.01 \pm 0.07^{\mathrm{b}}$ & $6.96 \pm 0.09^{\mathrm{a}}$ & $0.74 \pm 0.06^{\mathrm{b}}$ & $9.98 \pm 0.52^{\mathrm{a}}$ & $25.7 \pm 5.4^{\mathrm{b}}$ \\
\hline
\end{tabular}

Note: Means in the same column with different superscripts differ significantly $(\mathrm{P}<0.05)$. 
were more stable than in GRE because glucomannan concentration in GRE was influenced by environment at the time of A. oncophyllus growth.

Both glucomannan in GYP and GRE are polysaccharide from glucose and mannose. Glucomannan is mainly a straight-chain polymer, with a small amount of branching. The components sugar are $\beta-(1 \rightarrow 4)$ linked D-mannose and D-glucose in a ratio of 1.6:1 (Tien et al., 2009). The degree of branching is about $8 \%$ through $\beta-(1 \rightarrow 6)$-glucosyl linkages (Zhang et al., 2001). Glucomannan was non starch polysaccharide (Xu et al., 2013). Chemical structure of glucomannan is shown in Figure 2.

The high concentration of protein cannot produce high percentage of aflatoxin binding because glucomannan is not part of protein but is part of carbohydrate, especially polysaccharide. However, protein has stronger capability of binding to $\beta 1-4$ glucose-mannose than to Xylan because the affinity of protein to $\beta 1-4$ glucose-mannose is higher than to xylan. Binding protein with glucomannan made hydrogen binding between functional group of hydroxyl $(\mathrm{OH})$ in glucomannan and $\mathrm{O}_{2}$ or $\mathrm{NH}_{2}$ of amino acid residues of protein (Flint et al., 2004).

GRE has potential to bind aflatoxin based on in vitro testing. Application of this research (in vitro) for further research (in vivo) has a good prospect that GYP

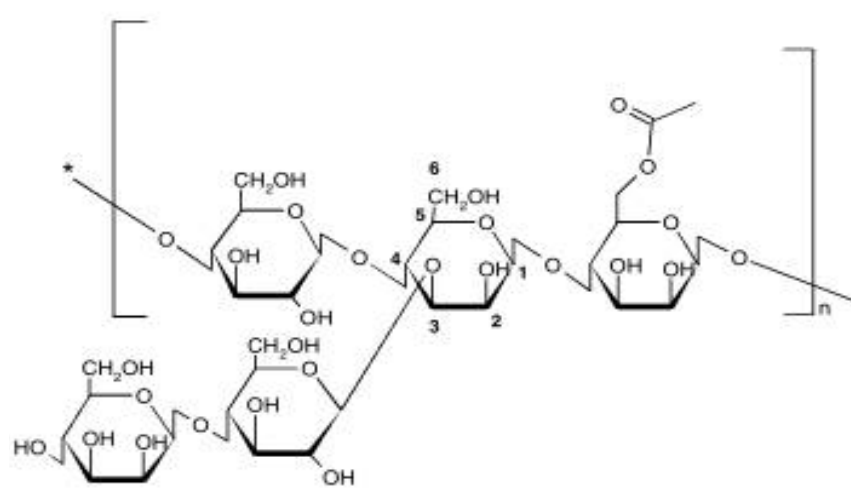

Figure 2. Chemical structure of glucomannan (Sande et al., 2009). become a good feed additive because it is safe for use in animal such as poultry. Feed containing 4000 ppm polysaccharide mannan decreased $(\mathrm{P}<0.01)$ Salmonella typhimurium and without decreasing the feed palatability in poultry. Addition of 4000 ppm mannan gave a significantly higher feed/weight gain ratio of the chicks $(\mathrm{P}<0.05)$. The administration of feed supplemented with mannan from palm kernel cake did not influence weight gain of poultry (Tafsin, 2007).

\section{Theory of Aflatoxin and Glucomannan Binding}

The molecule of glucomannan reacts with aflatoxin by hydrogen bonding because $\mathrm{C}=\mathrm{O}$ functional group of aflatoxin oxidized -OH functional group of glucomannan. Widjonarko et al. (2011) reported that molecule structure of glucomannan extracted from Amorphophalus konjac was well known by the presence of hydroxyl $(-\mathrm{OH})$ groups. The data are strongly confirmed by Zhang et al. (2001) that glucomannan spectra in Forier Transform Infrared Spectroscopy (FTIR) analysis are dominated by a broad band assigned to the stretching vibration modes of $-\mathrm{OH}$ groups and water.

Each molecule of aflatoxin has two $\mathrm{C}=\mathrm{O}$ functional groups (Figure 3) and each molecule of glucose or mannose has $5-\mathrm{OH}$ fuctional groups, so that they have a higher capability to bind reciprocally and produced $\mathrm{H}_{2} \mathrm{O}$. Aflatoxin-glucomannan binding make a complex of compound which cannot be absorbed in the intestine of animal and eliminated with feces that protect the animal from the attack of aflatoxin. Model of aflatoxin binding with glucomannan that processed by Chem Draw Ultra 8.0 is presented in Figure 4.

Recent research showed that in vitro experiment alone on aflatoxin binding only serve to screen potentially useful materials. In vitro test should be confirmed by in vivo experiments designed to demonstrate both safety and efficacy. In vitro testing of GYP and GRE showed the potential ability to bind aflatoxin. Therefore, those two binders should be augmented in vivo testing, so that true binding capacity to aflatoxin in animal body is known.

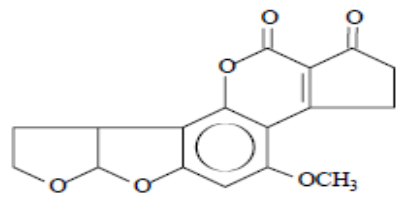

$\mathrm{B}_{2}: \mathrm{C}_{17} \mathrm{H}_{14} \mathrm{O}_{6} \quad$ Mol. wt: 314.3

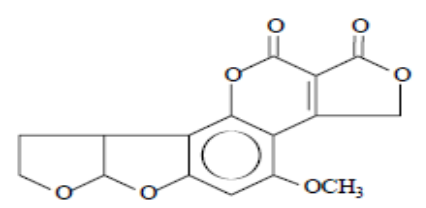

$\mathrm{G}_{2}: \mathrm{C}_{17} \mathrm{H}_{14} \mathrm{O}_{7} \quad$ Mol. wt: 330.3

$\mathrm{G}_{1}: \mathrm{C}_{17} \mathrm{H}_{12} \mathrm{O}_{7} \quad$ Mol. wt: 328.3

Figure 3. Chemical structures of several aflatoxin types (IARC, 2002) 


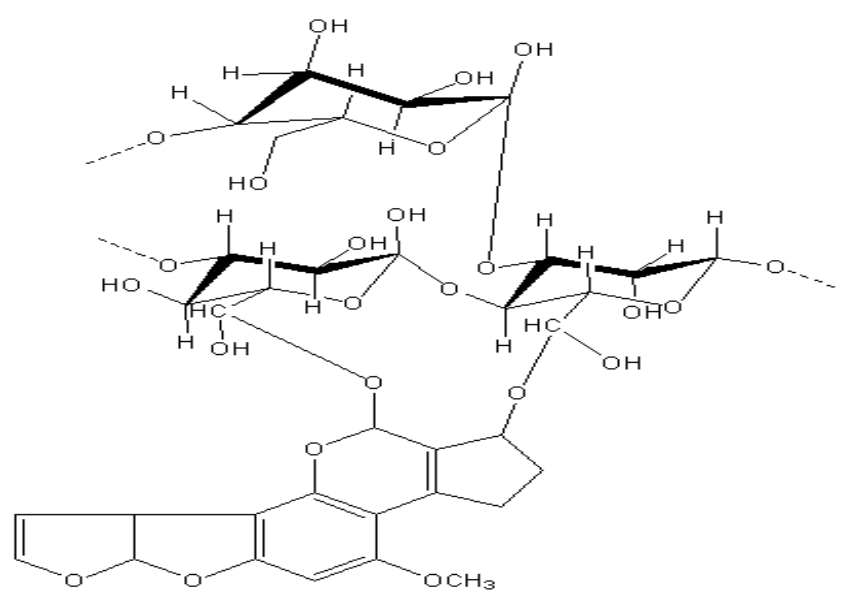

Figure 4. Theory of glucomannan binding with aflatoxin (processed by Chem DrawUltra 8.0). Chemical structure of glucomannan and aflatoxin according to Sande et al. (2009) and IARC (2002), respectively.

\section{Application of GRE}

GRE had a good ability of binding to aflatoxin in vitro and indeed the percentage of aflatoxin binding of GRE was higher than that of GYP. Therefore, GRE can become a candidate for feed additive as a aflatoxin binder because in vitro is only screening test (Gallo \& Masoero, 2010). In vitro testing only used part of an animal and this experiment was only used gastrointestinal fluid of broiler. For application to animal, GRE must be test in vivo on live animal.

According to the European Food Safety Authority (2010), both in vitro and in vivo testing are required for the assessment of mycotoxin binders because we need information about the interaction of mycotoxin binder with other nutritions in alimentarius duct. The critical point of mycotoxin binder is its low selectivity, so that it can bind not only mycotoxin but also other nutritions.

\section{CONCLUSION}

Extract from tuber A. oncophyllus contained glucomannan which can bind aflatoxin in in vitro testing. The percentages of aflatoxin binding by GRE and GYP were $89.07 \%$ and $46.35 \%$, in the ratio of aflatoxin : binder of $1: 10^{6}$. Glucomannan extracted from $A$. oncophyllus has a potential to bind aflatoxin, so that it should be continued in in vivo experiment.

\section{REFERENCES}

Abbes, S., J. B. Abbes, M. Moun, M. Ibrahim, M. Wahab, H. Bacha, \& R. Queslati. 2008. Efficacy of Tunisian montmorillonite for in vitro aflatoxin binding and in vivo amelioration of physiological alterations. Applied Clay Sci. 42: 151157. http://dx.doi.org/10.1016/j.clay.2008.01.004

Akkaya, M. \& M. Bal. 2012. Efficacy of modified yeast extract and mycotoxin adsorbent on ruminal binding characteristics of various aflatoxins. Kafkas Univ.Vet. Fak. Derg 18:951-955.
Basmacioglu H., H. Oguz, M. Ergul, R. Col, \& Y. O. Birdane. 2005. Effect of Dietary Esterified Glucomannan on Performance, Serum Biochemistry and Haematology in Broilers Exposed to Aflatoxin. Czech. J. Anim. Sci. 50:31-39.

Denli, M., J. C. Blandon, M. E. Guynot, S. Salado, \& J. F. Perez. 2009. Effects of dietary AflaDetox on performance, serum biochemistry, histopathological changes, and aflatoxin residues in broilers exposed to aflatoxin $\mathrm{B}_{1}$. Oxf. J. 88:14441445.

Devegowda, G. \& T. N. K. Murthy. 2005. Mycotoxins: Their Adverse Effect in Poultry and Some Practical Solution in the Mycotoxin Blue Book. $1^{\text {st }}$ ed. Nottingham: Nottingham Univ Pr. Pp. 25-56.

EFSA (European Food Safety Authority). 2010. Statement on the establishment of guidelines for the assessment of additives from the functional group "substances for reduction of the contamination of feed by mycotoxins"e. EFSA J. 8.

Evans, J. \& K. Dawson. 2007. The ability of Mycosorb to bind toxins present in endophyte-infected tall fescue. Science and Technology in the Feed Industry. North American Biosciences center, Alltech Inc.

Flint J, D. Nurizzo, S. Harding, E. Gideon, J. Davies, H. Gilbert, \& D. Bolam. 2004. Ligand-mediated dimerization of Carbohydrate binding module reveals a novel mechanism for protein-carbohydrate recognition. J. Mol. Biol. 377:417426. http://dx.doi.org/10.1016/j.jmb.2003.12.081

Gallo, A. \& F. Masoero. 2010. In vitro models to evaluate the capacity of different sequestering agents to adsorb aflatoxins. Ital. J. Anim.Sci. 9:109-116.

Hesham, M, Teleb, A. Hegazy, \&Y. Hussein. 2004. Efficiency of kaolin and activated charcoal to reduce the toxicity of low level of aflatoxin in broiler. Sci. J. King Faisal Univ. 5:145-160.

IARC (International Agency for Research on Cancer). 2002. IARC monograph on the evaluation of carcinogenic risks to human. Vol 82. http://monograph. http://monographs. iarc.fr/ENG/Monographs/vol82/index.php [1 September 2014].

IARC (International Agency for Research on Cancer). 2012. Agents Classified by the IARC Monographs, France, 1-109 http://monograph.iarc.fr/ENG/classification/ [15 Pebruari 2014].

Ohtsuki, T. 1968. Studies on Reserve Carbohydrates of Flour Amorphophallus Species with Special Reference to Mannan. Botanical Magazine Tokyo 81:119-126. http://dx.doi. org/10.15281/jplantres1887.81.119

Kaki, S., M. M. Moeni, \& J. Cheragi. 2012. Effects of zeolite and mycosorb on serum biochemical and hematological parameter of broilers chicken aflatoxicosis. J. Blood Lymph.2:1-4.

Manafi, M., H. D. Narayanaswamy, \& D. Pirany. 2009. In vitro binding ability of binder in commercial broiler feed. Afric. J. Agric. research 4:141-143.

Moschini, M., A. Gallo, G. Piva, \& F. Masoero. 2008. The effects of rumen fluid on the in vitro aflatoxin binding capacity of different sequestering agents and in vivo release of the sequestered toxin. Anim. Feed Sci.Tech. 147:292-309. http://dx.doi.org/10.1016/j.anifeedsci.2008.01.010

Nuryono, A. Agus, S. Wedhastri, Y. M. S. Maryudhani, D. Pranowo, Yunianto, \& R. Fazeli. 2012. Adsorption of aflatoxin B1 in corn on natural zeolite and bentonite. Indones. .J Chem. 12:279-286.

Rensburg, J. V., C. E. J. Rensburg, B. J. Ryssen, N. H. Casey, \& G. E. Rottinghaust. 2006. In vitro and in vivo assessment of humic acid as an aflatoxin binder in broiler chickens. Poultry Sci. 85:1576-1583. http://dx.doi.org/10.1093/ ps/85.9.1576

Richard, E., N. Heutte, V. Bouchart, \& D. Garon. 2009. Evaluation of fungal contamination and mycotoxin production in 
Maize silage. Anim. Feed. Sci. Technol.148:309-320. http:// dx.doi.org/10.1016/j.anifeedsci.2008.02.004

Sande, M. A., D. T. Osorio, R. Lopez, \& M. J. Alonso. 2009. Glucomannan, a promising polysaccharide for biopharmaceutical purposes. Europ. J. Pharm. Biopharm. 72:453-462

Siddappa V, D. K. Nanjegowda, \& P. Viswanath. 2012. Occurrence of aflatoxin M1 in some samples of UHT, raw \& pasteurized milk from Indian states of Karnataka and Tamilnadu. Food Chem. Toxic. 50: 4158-4162. http://dx.doi. org/10.1016/j.fct.2012.08.034

[SNI] Standar Nasional Indonesia. 1992. Metode Pengujian Kadar Karbohidrat 01-2891-1992 butir 9. Badan Standarisasi Nasional, Jakarta.

Tafsin, M., L. A. Sofyan, N. Ramli, K. G. Wiryawan, K. Zarkasie, \& W. G. Piliang. 2007. Polisakarida mengandung mannan dari bungkil inti sawit sebagai antimikroba Salmonella typphimurium pada ayam. Med. Pet. 30:139-146.
Tien N., D. Thien, N. Dong, P. Dung, \& N. Du. 2009. Characterization of polysaccharide from Amorphophallus paeoniifolius in Vietnam. J Chem. 47:155-159.

Widjanarko, S. B., A. Nugroho, \& T. Estiasih. 2011. Functional interaction components of protein isolates and glucomannan in food bars by FTIR and SEM studies. Afric. J. Food Sci. 5: 12-21.

Xu, M., D. S. Li, B. Li, C. Wang, Y. P. Zhu, W. Ping, \& B. J. Xie. 2013. Comparative study on molecular weight of Konjac glucomannan by gel permeation chromatography-laser light scattering-refractive index and laser light-scattering methods. J. Spectroscopy 2013 Article ID 685698, 4 pages.

Zhang, H., M. Yoshimura, K. Nishinari, M. K. Williams, T. J. Foster, \& I. T. Norton. 2001. Gelation behaviour of Konjac Glucomannan with different moleculear weight. J. Biopolymers 59: 38-50. http://dx.doi.org/10.1002/10970282(200107)59:1<38::AID-BIP1004>3.0.CO;2-A 